\title{
Enantioselective Detoxication of Optical Isomers of Glycidyl Ethers
}

\author{
RUTH CHEN, PHUONG NGUYEN, ZHENGQING YOU, AND JOSEPH E. SINSHEIMER \\ College of Pharmacy, University of Michigan, Ann Arbor, Michigan
}

\begin{abstract}
The detoxication of the enantiomers of glycidyl 4-nitrophenyl ether (GNPE), (-)-(R)- and (+)-(S)-GNPE, and glycidyl 1-naphthyl ether (GNE), (-)-(R)- and $(+)-(\mathrm{S})-\mathrm{GNE}$, by rat liver glutathione transferase and epoxide hydrolase was studied. Enantioselectivity was observed with both enzymes favoring the (R)-isomers as determined by the formation of conjugate, diol, and remaining substrate measured by HPLC. Enantiomers of GNE were detoxified by cytosolic epoxide hydrolase but those of GNPE were not. Substantial nonenzymatically formed conjugates of enantiomers of GNPE were detected showing (S)-GNPE the more reactive of the pair. (1) 1993 Wiley-Liss, Inc.
\end{abstract}

KEY WORDS: glycidyl 1-naphthyl ether enantiomers, glycidyl 4-nitrophenyl ether enantiomers, glutathione conjugation, epoxide hydrolase, diol formation

Epoxides, with the presence of a highly strained oxirane ring, are reactive alkylating agents and are widely used as industrial intermediates and laboratory reagents. This widespread use and the reactivity of these epoxides have raised concerns about their possible occupational and environmental toxicity. ${ }^{1,2}$ Also, analogous to the concept that the genotoxicity of polycyclic aromatic hydrocarbons is due to the metabolic formation of arene oxides, there is the question of possible toxicity due to the metabolic formation of aliphatic epoxides from their olefinic precursors. ${ }^{3,4}$ Recently, there has been an increased availability and use of the enantiomers of epoxides in highly purified form as reagents for chiral synthesis. ${ }^{5}$ Differences in the in vitro genotoxicity for the (R)- versus (S)isomers of some of these reagents have been established. ${ }^{6}$ As part of a study in progress to investigate the differences in genotoxicity between epoxide enantiomers, we are testing the hypothesis that the chirality of aliphatic epoxides will affect their detoxication.

For this purpose, we have synthesized the (R)- and (S)isomers of glycidyl 4-nitrophenyl ether (GNPE) and the isomers of glycidyl 1-naphthyl ether (GNE) (Fig. 1) so as to explore the enantioselectivity of these compounds by the glutathione transferase and epoxide hydrolase systems in liver homogenate subfractions. GNPE and GNE were found to be among the stronger genotoxic aliphatic epoxides when tested as their racemates in vitro ${ }^{7,8}$ and in vivo. ${ }^{9,10}$

\section{MATERIALS AND METHODS Chemicals}

Rac-glycidyl 4-nitrophenyl ether was obtained from Eastman Kodak (Rochester, NY) and purified by repeated recrystallization from ethanol; 4-nitrophenol, 1-naphthol, (-)-(2R)and $(+)-(2 S)$-glycidyl 3-nitrobenzenesulfonate, rac-glycidyl 1-naphthyl ether, and dimethyl sulfoxide (DMSO) were pur- chased from Aldrich (Milwaukee, WI); glutathione reduced form (GSH) was obtained from Sigma (St. Louis, MO).

\section{Synthesis}

The enantiomers of GNPE and GNE were synthesized according to the method of Klunder et al. ${ }^{11}$ with $(+)-(2 S)-$ or (-)-(2R)-glycidyl 3-nitrobenzenesulfonate and 4-nitrophenol or 1-naphthol, respectively. After purification through a silica gel column with a mixture of hexane and ethyl acetate (2:1) for (R)- and (S)-GNPE and hexane and ethyl acetate (3:1) for (R)and (S)-GNE, the following yields are obtained: (R)-GNPE, 64\%; (S)-GNPE, 65\%; (R)-GNE, 94\%; and (S)-GNE, 92\%. The GNPE isomers were solids further purified by crystallization from methanol to yield white needles. (R)- and (S)-GNE appeared as slightly yellow oils. NMR analysis with the shiftreagent $\mathrm{Eu}(\mathrm{hfc})_{3}{ }^{12}$ was employed to determine the enantiomeric excess (\%ee). (R)-GNPE: mp 77-78 C; $[\alpha]^{20}{ }_{\mathrm{D}}-5.1^{\circ}$ (c $0.5, \mathrm{CHCl}_{3}$ ); \%ee $\geqslant 98$. (S)-GNPE: $\operatorname{mp} 77.5-78^{\circ} \mathrm{C} ;[\alpha]^{20}{ }_{\mathrm{D}}$ $+4.9^{\circ}$ (c $\left.0.6, \mathrm{CHCl}_{3}\right)$; \%ee $\geqslant 98$. (R)-GNE: $[\alpha]^{20}{ }_{\mathrm{D}}-16.4^{\circ}$ (c 2, $\mathrm{CHCl}_{3}$ ); \%ee $=92$. (S)-GNE: $[\alpha]^{20}$ D $+17.3^{\circ}$ (c 2, $\left.\mathrm{CHCl}_{3}\right) ; \%$ ee $=93$. NMR spectra for both enantiomers of $\mathrm{GNPE}^{13}$ and $\mathrm{GNE}^{11}$ were as previously reported.

Reference diols of rac-GNPE [ $r a c-2,3$-dihydroxy-1-( $p$-nitrophenoxy)propane] and rac-GNE [rac-2,3-dihydroxy-1-(1naphthoxy)propane] were synthesized by the hydrolysis of the respective epoxides in acetone with perchloric acid. They were purified by silica gel chromatography with ethyl acetate and appeared as white powders with $\mathrm{mp}$ of $67-69^{\circ} \mathrm{C}$ and 95 $97^{\circ} \mathrm{C}$, respectively.

Received for publication November 10, 1992; accepted April 15, 1993. Address reprint requests to Dr. J.E. Sinsheimer, College of Pharmacy, University of Michigan, Ann Arbor, MI 48109-1065. 


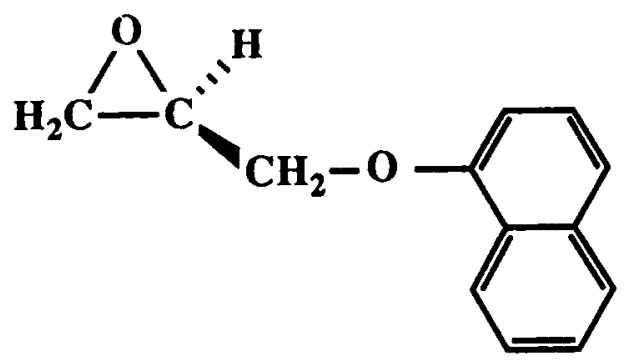

(R) - GNE

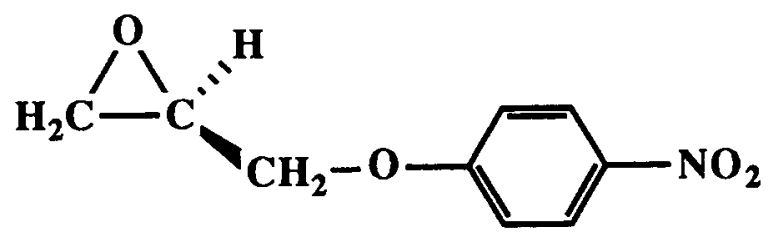

(R) - GNPE

Fig. 1. Chemical structures for (R)-(-) glycidyl 4-nitrophenyl ether (GNPE) and (R)-(-) glycidyl 1-naphthyl ether (GNE).

Rac-2,3-dihydroxy-1-(p-nitrophenoxy)propane: ${ }^{1} \mathrm{H} \quad$ NMR $\left(\mathrm{CDCl}_{3}, 300 \mathrm{MHz}\right) \delta 8.214$ (d, $J=9.2 \mathrm{~Hz}, 2 \mathrm{H}$, aromatic), $6.992(\mathrm{~d}, J=9.2 \mathrm{~Hz}, 2 \mathrm{H}$, aromatic), $4.22-4.11(\mathrm{~m}, 3 \mathrm{H})$, $3.92-3.74(\mathrm{~m}, 2 \mathrm{H}), 2.589$ (d, $J=4.3 \mathrm{~Hz}, 1 \mathrm{H}, \mathrm{CHOH})$, $1.999\left(\mathrm{t}, J=5.8 \mathrm{~Hz}, 1 \mathrm{H}, \mathrm{CH}_{2} \mathrm{OH}\right)$.

Rac-2,3-dihydroxy-1-(1-naphthoxy)propane: $\quad{ }^{1} \mathrm{H} \quad$ NMR $\left(\mathrm{CDCl}_{3}, 300 \mathrm{MHz}\right) \delta 8.207(\mathrm{~m}, 1 \mathrm{H}$, aromatic), $7.804(\mathrm{~m}, 1 \mathrm{H}$, aromatic), $7.49(\mathrm{~m}, 2 \mathrm{H}$, aromatic), $7.455(\mathrm{~d}, J=8.3 \mathrm{~Hz}, 1 \mathrm{H}$, aromatic), 7.362 (dd, $J=8.3,7.5 \mathrm{~Hz}, 1 \mathrm{H}$, aromatic), 6.822 (d, $J=7.5 \mathrm{~Hz}, 1 \mathrm{H}$, aromatic), $4.30-4.19(\mathrm{~m}, 3 \mathrm{H}), 3.97-3.82$ $(\mathrm{m}, 2 \mathrm{H}), 2.790(\mathrm{~d}, J=4.5 \mathrm{~Hz}, 1 \mathrm{H}, \mathrm{CHOH}), 2.227(\mathrm{t}$, $J=6.0 \mathrm{~Hz}, 1 \mathrm{H}, \mathrm{CH}_{2} \mathrm{OH}$ ).

The reference GSH conjugates of $r a c-G N P E$ and $r a c-G N E$ were synthesized by the method of Van den Eeckhout et al. ${ }^{14}$ GSH and $r a c$-GNPE or rac-GNE were refluxed in acetonewater in the presence of sodium bicarbonate to form the respective conjugate obtained as a white solid after silica gel chromatography with $2 \mathrm{~N} \mathrm{NH}_{3}$ in methanol and ethanol (3:1).

Rac-GNPE GSH conjugate: ${ }^{1} \mathrm{H}$ NMR (DMSO-d6) $\delta 8.80$ (br s, $1 \mathrm{H}$, amide), 8.166 (d, $J=9.3 \mathrm{~Hz}, 2 \mathrm{H}$, aromatic), 7.94 (br s, $1 \mathrm{H}$, amide), 7.142 (d, $J=9.3 \mathrm{~Hz}, 2 \mathrm{H}$, aromatic), 4.47-4.31 (m, $1 \mathrm{H}), 4.17-3.92(\mathrm{~m}, 3 \mathrm{H}), 3.54-3.31(\mathrm{~m}, 3 \mathrm{H})$, 3.04-2.91 (m, $1 \mathrm{H}), 2.83-2.60(\mathrm{~m}, 3 \mathrm{H}), 2.43-2.24(\mathrm{~m}, 2 \mathrm{H})$, $2.04-1.86(\mathrm{~m}, 2 \mathrm{H}) .{ }^{13} \mathrm{C}$ NMR (DMSO-d6, 90.5 MHz) $\delta$ $172.81,172.54,172.12$, and $169.99(\mathrm{C}=0) ; 164.08,140.82$, 125.88 , and 115.15 (aromatic); $71.67,68.57,68.40,53.48$ (br), 53.08 (br), 43.67 (br), 35.26, 35.04, 34.22 (br), 31.67 (br), 27.07 (br). Mass spectrometry (MS) (positive ion FAB, 3:1 dithiothreitol/dithioerythritol matrix) $\mathrm{m} / \mathrm{z}$ calculated for $\mathrm{C}_{19} \mathrm{H}_{26} \mathrm{O}_{10} \mathrm{~N}_{4} \mathrm{SH}(\mathrm{M}+\mathrm{H})$ 503, found 503. This mixture of isomers chromatographed as a single spot on TLC with $2 \mathrm{~N}$ $\mathrm{NH}_{3}$ in methanol and ethanol (3:1). It also appeared as a single peak by HPLC (see HPLC below for conditions for chromatography).

Rac-GNE GSH conjugate: ${ }^{1} \mathrm{H}$ NMR (DMSO-d6, $300 \mathrm{MHz}$ ) $\delta 8.72$ (br s, $1 \mathrm{H}$, amide), $8.236(\mathrm{~m}, 1 \mathrm{H}$, aromatic), 8.16 (br s, $1 \mathrm{H}$, amide), $7.824(\mathrm{~m}, 1 \mathrm{H}$, aromatic), $7.48(\mathrm{~m}, 2 \mathrm{H}$, aromatic), $7.430(\mathrm{~d}, J=8.1 \mathrm{~Hz}, 1 \mathrm{H}$, aromatic), 7.375 (dd, $J=8.1,7.3 \mathrm{~Hz}, 1 \mathrm{H}$, aromatic), $6.930(\mathrm{~d}, J=7.3 \mathrm{~Hz}, 1 \mathrm{H}$, aromatic), $4.53-4.37(\mathrm{~m}, 1 \mathrm{H}), 4.20-4.01(\mathrm{~m}, 3 \mathrm{H}), 3.64-3.38$ $(\mathrm{m}, 3 \mathrm{H}), 3.10-2.98(\mathrm{~m}, 1 \mathrm{H}), 2.94-2.71(\mathrm{~m}, 3 \mathrm{H}), 2.46-2.26$ $(\mathrm{m}, 2 \mathrm{H}), 2.07-1.87(\mathrm{~m}, 2 \mathrm{H}) .{ }^{13} \mathrm{C}$ NMR (DMSO-d6, 90.5 $\mathrm{MHz}) \delta 172.38,171.84$, and $170.08(\mathrm{C}=0) ; 154.12,134.02$, $127.34,126.45,126.27,125.23,125.03,121.94,119.92$, and 105.21 (aromatic): 70.98, 68.90, 68.67, 53.42, 53.30, 53.07, 43.22 (br), 35.64, 35.46, 34.26 (br), 31.64 (br), 27.02 (br). MS (positive ion FAB, 3:1 dithiothreitol/dithioerythritol matrix) $m / z$ calculated for $\mathrm{C}_{23} \mathrm{H}_{29} \mathrm{O}_{8} \mathrm{~N}_{3} \mathrm{SH}(\mathrm{M}+\mathrm{H}) 508$, found 508. This mixture of isomers chromatographed as a single spot on TLC with $2 \mathrm{~N} \mathrm{NH}_{3}$ in methanol and ethanol (3:1). It also eluted as a single peak by HPLC (see HPLC below for chromatography conditions).

\section{Enzymatic Reactions}

Liver homogenate fractions from male Sprague-Dawley rats $(160-180 \mathrm{~g}$, Charles River Breeding Laboratories, Wilmington, MA) were isolated as previously described. ${ }^{15}$ The protein concentrations of these fractions as determined by the Lowry procedure ${ }^{16}$ were $\mathrm{S} 9,7.4 \mathrm{mg} / \mathrm{ml}$; microsomal, 1.30 $\mathrm{mg} / \mathrm{ml}$; and cytosolic ( $\mathrm{S100)}, 5.27 \mathrm{mg} / \mathrm{ml}$. In addition to $50 \mu \mathrm{l}$ of DMSO solutions of GNPE $(5.12 \mu \mathrm{mol})$ or GNE ( $5 \mu \mathrm{mol})$, $50 \mu$ of a GSH solution ( $4.6 \mu \mathrm{mol}$ in $0.1 M$ phosphate buffer, $\mathrm{pH} 7.4), 50 \mu \mathrm{l}$ of liver homogenate fraction, and $800 \mu \mathrm{l}$ of phosphate buffer were added to determine glutathione transferase activity for both epoxides. The $0.95-\mathrm{ml}$ mixture was incubated at $37^{\circ} \mathrm{C}$ for $15 \mathrm{~min}$ which was determined to be on the linear phase of the formation of GSH conjugate and diol for both epoxides. The incubate tubes were placed in rapidly boiling water for $1 \mathrm{~min}$ to stop the enzymatic reactions, and thereafter immediately placed on ice. Then $50 \mu$ of 4 -hydroxypropiophenone ( $1 \mathrm{mg} / \mathrm{ml}$ DMSO) was added as internal standard (IS), and the incubate was centrifuged at $40 \mathrm{~kg}$ for $40 \mathrm{~min}$. The clear supernatant was collected for use in HPLC analysis.

\section{HPLC}

The system consisted of an Altex 110A pump, a Rhoedyne 1725 injector, a guard volume $(4.6 \times 10 \mathrm{~mm}$ packed with reverse-phase ODS, Upchurch, Oak Harbor, WA), a $\mathrm{C}_{18}$ reverse-phase column (Partisil PXS 10/25 ODS-3, Whatman, Clifton, NJ), and an Altex 153 UV detector (254 nm). The mobile phase for the separation of the enantiomeric GNPE and its metabolites was a mixture of aqueous ammonium formate $(12.6 \mathrm{mM}, \mathrm{pH} 5.13)$ and methanol (2.5 to 1$)$. The system for enantiomeric GNE and its metabolites was a mixture of aqueous ammonium formate $(25.3 \mathrm{mM}, \mathrm{pH} 5.13)$, methanol, and acetic acid (3:2:0.05). The flow rate for both separa- 
TABLE 1. Observed production of the conjugates and diols of the enantiomers of GNPE and GNE

\begin{tabular}{|c|c|c|c|c|c|c|c|c|c|c|c|}
\hline \multirow[b]{2}{*}{ Treatment } & \multicolumn{3}{|c|}{ Conjugate } & \multicolumn{3}{|c|}{ Diol } & \multicolumn{3}{|c|}{ Substrate remaining } & \multicolumn{2}{|c|}{$\begin{array}{c}\% \\
\text { Recovery }^{b}\end{array}$} \\
\hline & $\mathbf{R}$ & & $\mathrm{S}$ & $\mathrm{R}$ & & $\mathrm{S}$ & $\mathrm{R}$ & & $\mathrm{S}$ & $\mathrm{R}$ & $\mathrm{S}$ \\
\hline \multicolumn{12}{|l|}{ GNPE $(5.12 \mu \mathrm{mol})$} \\
\hline S9 & $\begin{array}{c}\mathrm{NS}^{c} \\
(0.13 \pm 0.02)^{d}\end{array}$ & & $\begin{array}{c}\text { NS } \\
(0.15 \pm 0.04)\end{array}$ & $\begin{array}{c}1.82 \pm 0.26 \\
(0.15 \pm 0.01)\end{array}$ & $* *$ & $\begin{array}{c}0.55 \pm 0.02 \\
(0.17 \pm 0.01)\end{array}$ & $3.02 \pm 0.36$ & $* *$ & $4.20 \pm 0.23$ & 95 & 93 \\
\hline S9 + GSH & $\begin{array}{c}3.39 \pm 0.14 \\
(0.96 \pm 0.17)\end{array}$ & $\begin{array}{c}* \\
* *\end{array}$ & $\begin{array}{c}3.74 \pm 0.32 \\
(1.91 \pm 0.19)\end{array}$ & $\begin{array}{c}1.04 \pm 0.24 \\
(0.14 \pm 0.00)\end{array}$ & $* *$ & $\begin{array}{c}0.40 \pm 0.02 \\
(0.13 \pm 0.01)\end{array}$ & $0.69 \pm 0.10$ & $* *$ & $0.96 \pm 0.17$ & 98 & 98 \\
\hline M & $\begin{array}{l}\mathrm{ND}^{e} \\
\mathrm{ND}\end{array}$ & & $\begin{array}{l}\text { ND } \\
\text { ND }\end{array}$ & $\begin{array}{c}1.73 \pm 0.68 \\
(0.12 \pm 0.01)\end{array}$ & $* *$ & $\begin{array}{c}0.49 \pm 0.02 \\
(0.10 \pm 0.01)\end{array}$ & $2.93 \pm 0.60$ & $* *$ & $4.46 \pm 0.14$ & 92 & 97 \\
\hline $\mathrm{M}+\mathrm{GSH}$ & $\begin{array}{c}\text { NS } \\
(0.97 \pm 0.05)\end{array}$ & $* *$ & $\begin{array}{c}\text { NS } \\
(1.73 \pm 0.03)\end{array}$ & $\begin{array}{c}0.74 \pm 0.03 \\
(0.07 \pm 0.00)\end{array}$ & $* *$ & $\begin{array}{c}0.21 \pm 0.03 \\
(0.07 \pm 0.01)\end{array}$ & $2.73 \pm 0.46$ & $*$ & $3.27 \pm 0.31$ & 89 & 96 \\
\hline S-100 & $\begin{array}{c}\text { NS } \\
(0.12 \pm 0.03)\end{array}$ & & $\begin{array}{c}\text { NS } \\
(0.13 \pm 0.03)\end{array}$ & $\begin{array}{c}\text { NS } \\
(0.05 \pm 0.01)\end{array}$ & & $\begin{array}{c}\text { NS } \\
(0.05 \pm 0.01)\end{array}$ & $4.51 \pm 0.22$ & $*$ & $4.79 \pm 0.14$ & 95 & 98 \\
\hline $\mathrm{S} 100+\mathrm{GSH}$ & $\begin{array}{c}3.56 \pm 0.22 \\
(0.92 \pm 0.06)\end{array}$ & $* *$ & $\begin{array}{c}3.45 \pm 0.36 \\
(1.83 \pm 0.17)\end{array}$ & $\begin{array}{c}\text { NS } \\
(0.04 \pm 0.00)\end{array}$ & & $\begin{array}{c}\text { NS } \\
(0.04 \pm 0.01)\end{array}$ & $1.01 \pm 0.25$ & * & $1.56 \pm 0.40$ & 95 & 94 \\
\hline \multicolumn{12}{|l|}{ GNE $(5.0 \mu \mathrm{mol})$} \\
\hline S9 & $\begin{array}{c}\text { NS } \\
(0.06 \pm 0.02)\end{array}$ & & $\begin{array}{c}\mathrm{NS} \\
(0.11 \pm 0.03)\end{array}$ & $\begin{array}{c}2.38 \pm 0.05 \\
(0.05 \pm 0.00)\end{array}$ & $* *$ & $\begin{array}{c}1.33 \pm 0.10 \\
(0.01 \pm 0.01)\end{array}$ & $2.32 \pm 0.06$ & $* *$ & $3.26 \pm 0.10$ & 97 & 97 \\
\hline $\mathrm{S} 9+\mathrm{GSH}$ & $\begin{array}{c}2.35 \pm 0.24 \\
(0.18 \pm 0.03)\end{array}$ & $* *$ & $\begin{array}{c}1.47 \pm 0.04 \\
(0.27 \pm 0.05)\end{array}$ & $\begin{array}{c}1.01 \pm 0.03 \\
(0.05 \pm 0.04)\end{array}$ & $* *$ & $\begin{array}{c}0.89 \pm 0.05 \\
(0.01 \pm 0.00)\end{array}$ & $1.45 \pm 0.29$ & $* *$ & $2.47 \pm 0.09$ & 96 & 97 \\
\hline $\mathbf{M}$ & $\begin{array}{l}\text { ND } \\
\text { ND }\end{array}$ & & $\begin{array}{l}\text { ND } \\
\text { ND }\end{array}$ & $\begin{array}{c}1.34 \pm 0.07 \\
(0.10 \pm 0.07)\end{array}$ & $* *$ & $\begin{array}{c}0.83 \pm 0.05 \\
(0.02 \pm 0.01)\end{array}$ & $3.42 \pm 0.14$ & $* *$ & $3.91 \pm 0.08$ & 96 & 95 \\
\hline $\mathrm{M}+\mathrm{GSH}$ & $\begin{array}{c}\text { NS } \\
(0.27 \pm 0.05)\end{array}$ & & $\begin{array}{c}\text { NS } \\
(0.22 \pm 0.03)\end{array}$ & $\begin{array}{c}1.08 \pm 0.10 \\
(0.06 \pm 0.06)\end{array}$ & $* *$ & $\begin{array}{c}0.46 \pm 0.03 \\
(0.02 \pm 0.01)\end{array}$ & $2.93 \pm 0.13$ & $*$ & $3.87 \pm 0.66$ & 94 & 94 \\
\hline $\mathrm{S} 100$ & $\begin{array}{c}\text { NS } \\
(0.11 \pm 0.10)\end{array}$ & & $\begin{array}{c}\text { NS } \\
(0.13 \pm 0.02)\end{array}$ & $\begin{array}{c}1.03 \pm 0.04 \\
(0.04 \pm 0.02)\end{array}$ & & $\begin{array}{c}0.46 \pm 0.03 \\
(0.01 \pm 0.01)\end{array}$ & $3.68 \pm 0.08$ & $*$ & $4.14 \pm 0.10$ & 97 & 97 \\
\hline $\mathrm{S} 100+\mathrm{GSH}$ & $\begin{array}{c}2.48 \pm 0.37 \\
(0.18 \pm 0.02)\end{array}$ & $* *$ & $\begin{array}{c}1.48 \pm 0.07 \\
(0.27 \pm 0.02)\end{array}$ & $\begin{array}{c}0.85 \pm 0.03 \\
(0.03 \pm 0.02)\end{array}$ & & $\begin{array}{c}0.33 \pm 0.03 \\
(0.02 \pm 0.01)\end{array}$ & $1.51 \pm 0.41$ & $*$ & $2.97 \pm 0.08$ & 97 & 96 \\
\hline
\end{tabular}

${ }^{a}$ Results are expressed as mean $\pm \mathrm{SD}$ in $\mu \mathrm{mol}(n=6)$.

${ }^{b}$ Each \% recovery is the mean of the ratios of the sum of conjugate, diol, and remaining substrate in each incubate to initial substrate.

${ }^{c}$ No significant difference determined over its negative control of boiled liver homogenate fraction.

${ }^{d}$ Nonenzymatically produced metabolites which are in parentheses.

e Not detectable.

* Significant difference observed between enantiomers at $P<0.05$.

** Significant difference observed between enantiomers at $P<0.01$.

tions was $1.5 \mathrm{ml} / \mathrm{min}$. The retention times for GNPE conjugate, GNPE diol, IS, and GNPE were, respectively, 3.8, 6.0, 8.8 , and $14 \mathrm{~min}$. The retention times for IS, GNE conjugate, GNE diol, and GNE were 4.8, 6.7, 8.2, and $19 \mathrm{~min}$. The chiral isomers of GNPE and GNE had the same retention times as those of their racemates. Enantiomeric epoxides and their metabolites were determined quantitatively from the ratios of their peak heights to that of IS.

\section{RESULTS AND DISCUSSION}

Observed detoxication products of enantiomers of GNPE by GSH transferase and epoxide hydrolase are shown in Table 1. In the $\mathrm{S} 9+\mathrm{GSH}$ and the $\mathrm{S} 100+\mathrm{GSH}$ fractions, a substantial amount of nonenzymatically produced conjugates of each GNPE isomer was detected in the controls (heat-inactivated liver homogenate fractions). As expected with a reactive chiral epoxide and chiral GSH, a difference in the yields of nonenzymatically formed GSH conjugate for the two GNPE isomers was detected. Significantly more GSH conjugate of (S)-GNPE (in the order of 2 to 1 ) was produced nonenzymat- ically than that of (R)-GNPE in all control fractions with GSH added. Taking into consideration this difference in nonenzymatic conjugate formation, the enzymatic contribution to the total yields of conjugates must favor (R)-GNPE over (S)GNPE in both $\mathrm{S} 100+\mathrm{GSH}$ and $\mathrm{S} 9+\mathrm{GSH}$ fractions. The GSH conjugate of GNPE isomers produced enzymatically in the $\mathrm{S} 100$ fractions accounted for that formed in the S9 fractions.

With respect to epoxide hydrolase detoxication of the enantiomers of GNPE, four times the yield of (R)-GNPE diol was detected in the $\mathrm{S} 9$ and the microsomal fractions compared to (S)-GNPE diol. No diol above controls was detected in the cytosolic fractions. Comparisons between total GSH conjugate and diol showed that formation of GSH conjugate is the dominant pathway in the detoxication of enantiomers of GNPE.

Detoxication of GNE by GSH transferase and epoxide hydrolase was also enantioselective (Table 1). Similar to GSH transferase detoxication of enantiomers of GNPE, significantly more GSH conjugate of (R)-GNE was produced than that of the (S)-GNE. In contrast to GNPE, only low levels of 
nonenzymatically produced conjugate of each enantiomer of GNE were observed. Epoxide hydrolase detoxication also significantly favored (R)-GNE. Unlike epoxide hydrolase detoxication of GNPE enantiomers, high levels of cytosolic epoxide hydrolase activity were observed. Formation of cytosolic diol of (R)-GNE was $42 \%$ of that in the S9 fraction while production of cytosolic diol of (S)-GNE accounted for $34 \%$ of that in the S9 fraction. Comparisons between the formation of GSH conjugates and diols show that the GSH transferase pathway is the dominant enzymatic detoxication pathway.

More (S)-GNPE and (S)-GNE than their (R)-isomers remained after incubation which is in agreement with greater formation of metabolites of the (R)-forms of both epoxides. Total recoveries of remaining substrate and the products in each fraction were in general high, indicating a lack of breakdown of substrates or metabolites and the absence of additional metabolites.

\section{CONCLUSION}

The enzymatic detoxication of the enantiomers of GNPE and GNE by GSH transferase and epoxide hydrolase was enantioselective and both favored (R)-GNPE and (R)-GNE. Thus, differences in metabolism between epoxide enantiomers, as reported above and that documented for styrene oxide isomers in separate epoxide hydrolase $e^{17,18}$ and GSH transferase ${ }^{18,19}$ systems, could be a factor in potential differences in toxicity between epoxide enantiomers. The metabolic differences with epoxide enantiomers would also have to be considered when comparing in vitro and in vivo evaluations of their toxicity.

\section{ACKNOWLEDGMENTS}

The authors express our gratitude to Mr. Charles Rospierski and Ms. Amanda Hammond for their technical expertise and helpful discussions. This research was supported by Grant R01ES03345 awarded by the National Institute of Environmental Health Sciences, PHHS.

\section{LITERATURE CITED}

1. Hine, C., Rowe, K., White, E. R., Darmer, K.I., Youngblood, G.T. Epoxy compounds. In: Patty's Industrial Hygiene And Toxicology. Ila. Clayton, G.D., Clayton, F.E. eds. New York: John Wiley \& Sons, 1981:2141-2215.
2. Ehrenberg, L., Hussain, S. Genetic toxicity of some important epoxides. Mutat. Res. 86:1-13, 1981.

3. Maynert, R.L., Forman, E.W., Watabe, T. Epoxides as obligatory intermediates in the metabolism of olefins to glycidols. J. Biol. Chem. 246:5234-5238, 1970.

4. Manson, M.M. Epoxides-is there a human health problem? Br. J. Ind. Med. 37:317-336, 1980.

5. Hanson, R.M. The synthetic methodology of nonracemic glycidol and related 2,3-epoxy alcohols. Chem. Rev. 91:436-475, 1991.

6. von der Hude, W., Carstensen, S., Gurtler, R., Obe, G. Structureactivity relationships of epoxides: Induction of sister-chromatid exchange in V79 cells by enantiomeric epoxides. Mutat. Res. 278:289-297, 1992.

7. Voogd, C.E., van der Stel, J.J., Jacobs, J.J.J.A.A. The mutagenic action of aliphatic epoxides. Mutat. Res. 89:269-304, 1981.

8. Neau, S.H., Hooberman, B.H., Frantz, S.W., Sinsheimer, J.E. Substituent effects on the mutagenicity of phenylglycidyl ethers in Salmonella typhimurium. Mutat. Res. 93:297-304, 1982.

9. Giri, A.K., Messerly, E.A., Chakraborty, P.K., Hooberman, B.H., Sinsheimer, J.E. DNA strand breaks in liver for four aliphatic epoxides in mice. Mutat. Res. 242:187-194, 1990.

10. Giri, A.K., Messerly, E.A., Sinsheimer, J.E. Sister chromatid exchange and chromosome aberrations for 4 aliphatic epoxides in mice. Mutat. Res. 224:253-261, 1990.

11. Klunder, J.M., Onami, T., Sharpless, K.B. Arenesulfonate derivatives of homochiral glycidol: Versatile chiral building blocks for organic synthesis. J. Org. Chem. 54:1295-1304, 1989.

12. Parker, D. NMR determination of enantiomeric purity. Chem. Rev. 91:1441-1457, 1991.

13. Butera, J.A., Bagli, J.F. Preparation of phenoxypropylpiperazines as class III antiarrhythmics. U.S. US 4994459 A 19 Feb. 1991.

14. Van den Eeckhout, E., Sinsheimer, J.E., Baeyens, W., De Keukeleire, D., De Bruyn, A., De Moerloose, P. Regioselectivity in the chemical and enzymatic reactions between glutathione and phenylglycidyl ether. Anal. Lett. 16:785-798, 1983.

15. Sinsheimer, J.E, Van den Eeckhout, E., Hooberman, B.H., Beylin, V.G. Detoxication of aliphatic epoxides by diol formation and glutathione conjugation. Chem. -Biol. Interact. 63:75-90, 1987.

16. Lowry, O.H., Rosebrough, N.J., Farr, A.L., Randall, R.J. Protein measurement with the Folin phenol reagent. J. Biol. Chem. 193:265-275, 1951.

17. Watabe, T., Ozawa, N., Yoshikawa, K. Stereochemistry in the oxidative metabolism of styrene by hepatic microsomes. Biochem. Pharmacol. 30: 1695-1698, 1981.

18. Watabe, T., Ozawa, N., Hiratsuka, A. Studies on metabolism and toxicity of styrene-VI. Regioselectivity in glutathione $S$-conjugation and hydrolysis of racemic, $R$ - and $S$-phenyloxiranes in rat liver. Biochem. Pharmocol. 32:777-785, 1983.

19. Hiratsuka, A., Yokoi, A., Iwata, H., Watabe, T., Satoh, K., Hatayama, I. Sato, K. Glutathione conjugation of styrene 7,8-oxide enantiomers by major glutathion transferase isoenzymes isolated from rat livers. Biochem. Pharmacol. 38:4405-4414, 1989. 